\title{
Analysis on the Coupling Coordination Development of Tourism Industry and Regional Economy in Guangdong Province*
}

\author{
Hui $\mathrm{Li}$ \\ Zhuhai College of Jilin University \\ Zhuhai, China
}

\begin{abstract}
As an emerging industry with strong comprehensiveness, tourism industry has promoted the development of regional economy. The development of regional economy has provided industrial foundation and guarantee for tourism industry, and is also an important foundation for the development of tourism industry. The two must coordinate with each other and advance each other to ensure the harmonious and healthy development of the two. This study establishes the coupling coordination index system of tourism industry and regional economy in Guangdong Province, and analyzes the coordination status of tourism industry and regional economy since 2000 in Guangdong Province.
\end{abstract}

Keywords-tourism industry; regional economy; coupling coordination

\section{INTRODUCTION}

The experience of many countries in developing tourism industry shows that within the scope of a regional economic capacity, the development of tourism industry can promote the development of the national economy and increase national income. The contribution of tourism industry to regional economic development is multi-faceted. First, the development of tourism industry can increase national income, and at the same time, promote the development of regional related industries. Secondly, the development of inbound tourism can expand foreign exchange income and become an important means for foreign exchange earnings. Third, the development of the tourism industry can provide employment opportunities for local residents. Finally, the development of the tourism industry is conducive to expanding economic cooperation and exchanges among regions.

*Projects: 1. Guangdong Provincial Education Department's 2018 Key Scientific Research Projects in Universities and Colleges: GuangdongHong Kong-Macao Greater Bay Area Tourism Industry and Regional Economic Coupling and Coordination Development Research, Project No. 2018WTSCX203.

2. Guangdong Provincial Education Department's Innovative and Strong School Project 2018 (Provincial Key Platform and Major Scientific Research Projects): Guangdong-Hong Kong-Macao Greater Bay Area Marine Tourism Talents Training Research. Project Number: 2018GXJK250.

\section{DEVELOPMENT OF TOURISM INDUSTRY AND REGIONAL ECONOMY}

The development of tourism industry is conducive to the optimization of regional economic structure and the upgrading of industrial structure, which is conducive to expanding domestic demand and promoting the coordinated development of regional economy. However, the development of the tourism industry also depends on the level of regional economic development, and requires a certain degree and level of regional economy as the basis and supporting conditions. The mechanism of regional economy promoting the development of tourism industry is mainly reflected in two aspects.

On the one hand, from the perspective of the realization of tourist tourism, the development of regional economy has increased the income of residents, improved the lifestyle of residents, and provided residents with higher income, longer leisure time and stronger tourism motivation, which have laid the foundation for the rapid development of the tourism industry. On the other hand, regional economic development has laid the foundation for the development of the tourism industry.

The tourism industry provides the impetus for regional economic development, and the regional economic development has laid the foundation for the development of tourism industry. The two develop harmoniously, and this coordinated development can play a greater role in the same time and in the same space. In other words, the coordinated development process between the tourism industry and the regional economy is a process in which the two are coordinated and related in the same time and region. This process is a process in which the tourism industry system acts on the regional economic system in the process of continuous development and evolution, and the regional economic system constantly reacts upon the tourism industry system. The mechanism of tourism industry promoting regional economic development is divided into income effect, foreign exchange earning effect, employment effect, industrial correlation effect, regional balance effect, etc. At the same time, the mechanism of regional economy promoting tourism industry development is divided into two levels: tourist level (the increase of disposable income, the 
increase of leisure time, the formation of tourism motivation) and tourism industry (financial effect, technical effect, image effect, basic effect, etc.).

\section{CONSTRUCTION OF INDEX SYSTEM FOR COUPLING COORDINATION DEVELOPMENT OF TOURISM INDUSTRY AND REGIONAL ECONOMY}

In physics, coupling refers to a phenomenon in which two (or more than two) systems or forms of motion affect each other through various interactions. Coupling is the degree to which a system or element interacts with each other. From the perspective of synergetics, the degree of coupling determines the order and structure of the system when it reaches the critical region, or determines the trend of the system from disorder to order. The key to the system from disorder to order is the coordination among the internal parameters of the system. It controls the characteristics and laws of the system. The degree of coupling is a measure of this coordination. Therefore, it can define the degree to which the tourism industry and the regional economy influence each other through their respective coupling elements as the coupling degree of tourism industry regional economic, and its size reflects the degree of coordination between the tourism industry and the regional economy. On the basis of clarifying the mechanism of mutual coordination and evolution between tourism industry and regional economy, the coupling coordination model of tourism industry and regional economic development is constructed by means of the calculation model of coordination, so as to analyze the dynamic evolution and coupling state of composite system composed of tourism industry and regional economic development.

In order to measure the degree of coupling and coordination between tourism industry and regional economy in Guangdong Province, this paper draws on the relevant research of the regional coupling coordination degree model, and sets the tourism industry index system and regional economic development index system. The selection of various indexes in the systematic coupled comprehensive evaluation index system not only considers the representativeness and comprehensiveness of indexes, but also considers the scientificity of index design and the logicality of internal connection, as well as the vertical and horizontal comparability. In terms of operability, it is necessary to base on the current statistical system and reserve sufficient space for the improvement of the evaluation system in the future. On the basis of the above principles, this paper establishes 22 secondary index systems under the first-level indicator system (tourism industry index system and regional economic indicator system). The specific indicator system is shown in "Table I" (all data are from 2001-2018 Guangdong Statistical Yearbooks).

TABLE I. INDEX SYSTEM FOR THE COUPLING COORDINATION OF TOURISM INDUSTRY AND REGIONAL ECONOMY IN GUANGDONG PROVINCE

\begin{tabular}{|c|c|c|c|c|c|}
\hline $\begin{array}{l}\text { Coupling } \\
\text { system }\end{array}$ & Indicator type & Weight & Unit & Indicator system & Weight \\
\hline \multirow{8}{*}{$\begin{array}{l}\text { Tourism } \\
\text { system }\end{array}$} & Income effect & 0.3 & 100 million & Gross revenue of domestic tourism & 1.0 \\
\hline & $\begin{array}{l}\text { Foreign exchange } \\
\text { earning effect }\end{array}$ & 0.2 & 100 million & Foreign exchange income from tourism & 1.0 \\
\hline & Employment effect & 0.3 & Thousands of people & Accommodation above quota + catering staff & 1.0 \\
\hline & \multirow{5}{*}{ Industrial effect } & \multirow{5}{*}{0.2} & Thousands of people & Receiving domestic tourists & 0.25 \\
\hline & & & Thousands of people & Receiving foreign tourists & 0.25 \\
\hline & & & Number & Number of travel agencies & 0.2 \\
\hline & & & Number & Number of hotels with more than four stars & 0.2 \\
\hline & & & 100 million & $\begin{array}{l}\text { Total sales of wholesale and retail trade and catering } \\
\text { industry goods above the designated amount }\end{array}$ & 0.1 \\
\hline \multirow{14}{*}{$\begin{array}{l}\text { Regional } \\
\text { economic } \\
\text { system }\end{array}$} & \multirow{4}{*}{ Money effect } & \multirow{4}{*}{0.4} & 100 million & GDP & 0.1 \\
\hline & & & 100 million & Tertiary industry & 0.2 \\
\hline & & & 100 million & Fiscal revenue & 0.2 \\
\hline & & & 100 million & Fiscal expenditure & 0.5 \\
\hline & \multirow{5}{*}{ Basic effect } & \multirow{5}{*}{0.2} & 100 million & New urban fixed assets & 0.1 \\
\hline & & & Kilometre (km.) & The length of the road & 0.3 \\
\hline & & & Square meter & Urban per capita park green area & 0.2 \\
\hline & & & $\%$ & The built-up afforestation covers & 0.1 \\
\hline & & & 100 million & Throughput of post and telecommunications & 0.3 \\
\hline & \multirow{3}{*}{ Income state } & \multirow{3}{*}{0.2} & Yuan & Per Capita GDP & 0.2 \\
\hline & & & Yuan & The net income per farmer & 0.3 \\
\hline & & & Yuan & The average annual salary of on-the-job employees & 0.5 \\
\hline & \multirow[t]{2}{*}{ Image effect } & \multirow[t]{2}{*}{0.2} & Number & $\begin{array}{l}\text { Number of persons above the quota in the catering } \\
\text { industry }\end{array}$ & 0.5 \\
\hline & & & Number & Number of persons above the quota in the hotel industry & 0.5 \\
\hline
\end{tabular}

\section{EMPIRICAL ANALYSIS OF COUPLING COORDINATION} BETWEEN TOURISM INDUSTRY AND REGIONAL ECONOMY IN GUANGDONG PROVINCE

As a major tourist province, Guangdong has always been at the forefront of inbound tourism. In the more than 20 years since the reform and opening up, the inbound tourism market in Guangdong Province has formed a scale. Before 1990, China was at the foundation and development stage of inbound tourism, and the number of inbound tourists in Guangdong Province accounted for more than $90 \%$ of the national total. After 1990, the national tourism industry 
began to develop and inbound tourism entered a stage of rapid development. Since 2000, the foreign exchange income of inbound tourism has increased from 4,112.21 million US dollars to 19960.4 million US dollars in 2017. In the past 17 years, tourism foreign exchange income has accounted for more than $25 \%$ of the national tourism foreign exchange income, and the number of inbound tourists has increased from 11.9989 million to 365.452 million people in 2017. In the past 17 years, the number of inbound tourists has accounted for more than $30 \%$ of the national total.

Through the above-mentioned indicator system, the data of Guangdong Province from 2000 to 2017 will be collected. The relevant data of 2000, 2005, 2010, 2015 and 2017 will be selected for calculation. The results are shown in "Table II". Since 2000, the coordination between the tourism industry and the regional economy in Guangdong Province has not changed much. There has been no change since 2005 but it is at barely co-ordinated levels.

TABLE II. VALUE AND EVAluation OF THE COUPLING COORDINATION AND COORDINATED DEVELOPMENT OF TOURISM AND REGIONAL ECONOMY IN GUANGDONG PROVINCE

\begin{tabular}{|l|l|l|l|l|}
\hline Year & F1 & F2 & C & D \\
\hline 2000 & 0.100 & 0.056 & 0.48 & 0.27 \\
\hline 2005 & 0.137 & 0.134 & 0.50 & 0.37 \\
\hline 2010 & 0.215 & 0.182 & 0.50 & 0.44 \\
\hline 2015 & 0.331 & 0.289 & 0.50 & 0.56 \\
\hline 2017 & 0.397 & 0.338 & 0.50 & 0.61 \\
\hline
\end{tabular}

After further calculations, it was found that the coordinated development of Guangdong Province continued to rise, from 0.27 in 2000 to 0.61 in 2017 , from moderate imbalance to primary coordination. It shows that the level of coordinated development of the two is relatively high, which is consistent with the status and importance of Guangdong's tourism industry and regional economy in the country. Since 2000, the scores of the tourism system have been higher than those of the regional economic system, indicating that the overall development of tourism in Guangdong Province is better than the development of regional economy in the whole country, which is related to the actual development of tourism and regional economy in Guangdong Province. The international tourism foreign exchange income has been more than $25 \%$ of the national total, the number of inbound tourists accounted for more than $30 \%$ of the country; and Guangdong's GDP accounted for about $10 \%$ of the national total.

\section{CONCLUSION}

The development of tourism in Guangdong Province has a comparative advantage compared with the development of regional economy. However, there are also many problems and shortcomings in tourism. For example, compared with the national average, the growth rate of foreign exchange income of Guangdong international tourism is lower than that of the whole country. In terms of structural composition, the proportion of the department of Guangdong's international tourism industry fluctuates greatly. The overall professionalization level of Guangdong's international tourism industry is relatively low, and the differences between departments are large. Among the specialized sectors, the advantages of the transportation sector are outstanding. Among the non-specialized sectors, the specialization varies greatly from year to year, showing the characteristics of volatility development and insufficient stability. The optimization of Guangdong's international tourism industry structure lags behind the optimization and adjustment of the national international tourism industry structure, and the optimization trend is not obvious. In the future, the optimization of the tourism industry structure will be improved, achieving a high level of industrial structure optimization and further increasing the tourism industry's role in promoting the regional economy.

\section{REFERENCES}

[1] Liu Danli, Wang Xia, Wu Xiaogen, He Jing, Duan Zhiyong Coupling coordination between tourism competitiveness and economic development in global poverty-stricken countries and spatiotemporal changes $[\mathrm{J}]$. Progress in Geography, 2018,37(10):1381-1391. (in Chinese)

[2] Yang Xiuping, Zhang Dacheng. Study of Coupling Coordination between Tourism Economy and the New Urbanization: Taking Lanzhou City as an Example [J], Ecological Economy, 2018,34(08):112-117. (in Chinese)

[3] Xu Jiaping, Zheng Lin. The Coupling and Coordination Relationship between Tourism Industry and Regional Economy in Fujian Province [J]. Jiangxi Science, 2018, 36(01): 195-202. (in Chinese)

[4] Wu Xu, Pang Shiming. Analysis of the Coordination and Coordination Degree between Tourism Industry and Regional Economy - Taking Beijing as a Case [J]. Journal of Commercial Economics, 2017(24):150-152. (in Chinese)

[5] Wang Lulu, Yu Hu, Zhou Bin. Analysis of Coupling Coordination Degree between Zhejiang Tourism Industry and Regional Economic Development [J]. Areal Research and Development, 2017, 36(06): 87-92. (in Chinese)

[6] Guo Xiangyang, Mu Xueqing,Ming Qingzhong. Coupling Space Situation of Tourism Economy and Traffic System in Yunnan [J] Economic Geography, 2017, 37(09): 200-206. (in Chinese)

[7] Zhang Yuping, Wahapu Halike, Dang Jianhua, Deng Baoshan, Wang Ran. Coupled coordination degree of tourism-economy-ecological system in Turpan Area [J]. Human Geography, 2014, 29(04): 140-145. (in Chinese)

[8] Zhan Xinhui, Ma Yaofeng, Liu Junsheng. The Coupling Coordination Evolution Between Inbound Tourist Flow and Regional Economy in China - A Case Study of Henan Province [J]. Henan Science, 2013, 31(06): 913-919. (in Chinese)

[9] Li Youlong, Hu Min, Ma Yaofeng. Analysis on Coupling Degree of Coordination between Flow of Inbound Tourism in Xinjiang and Regional Economic [J]. Resource Development \& Market, 2013, 29(04): 418-421. (in Chinese)

[10] Zhong Xia, Liu Yihua. Coupled Coordination Degree of TourismEconomy-Ecological System in Guangdong Province [J]. Tropical Geography, 2012, 32(05): 568-574. (in Chinese)

[11] Liu Dinghui, Yang Yongchun. Anhui province tourism industry and district economy cooperative analysis [J]. Special Zone Economy, 2011(06): 188-190. (in Chinese) 